\title{
PERUBAHAN WARNA RESIN KOMPOSIT NANOFILLER SETELAH PERENDAMAN DALAM MINUMAN SUSU FERMENTASI (PENELITIAN IN VITRO)
}

\author{
Istibsyaroh, Sri Lestari, Raditya Nugroho \\ Fakultas Kedokteran Gigi Universitas Jember \\ e-mail korespondensi: istibsyar@live.com
}

\begin{abstract}
Abstrak
Resin komposit adalah salah satu jenis bahan tumpatan gigi anterior yang populer karena memiliki kelebihan dalam bidang estetik dan sewarna gigi. Komposit nanofiller memiliki sifat mekanik lebih baik dibandingkan microhybrid dan dapat mempertahankan kehalusan selama pemakaian setara microfiller. Resin komposit dapat mengalami perubahan warna di dalam rongga mulut, salah satunya dapat disebabkan oleh minuman dengan $\mathrm{pH}$ rendah. Tujuan penelitian adalah mengetahui adanya pengaruh perendaman di dalam minuman susu fermentasi terhadap perubahan warna resin komposit nanofiller. Selain itu untuk mengetahui adanya perbedaan perubahan warna resin komposit nanofiller selama perendaman 6, 12, dan 18 jam. Jenis penelitian yang digunakan adalah eksperimental laboratories dengan rancangan penelitian desain grup pretest and post test. Sampel berjumlah 24 direndam dalam susu fermentasi selama 6, 12, dan 18 jam. Pengukuran perubahan warna menggunakan spektrofotometer optik untuk mengetahui nilai intensitas cahaya. Nilai perubahan warna tampak pada besarnya nilai intensitas cahaya yang muncul pada alat spektrofotometer optik. Analisis data menggunakan uji Paired-T Test dan One Way Annova. Nilai uji intensitas cahaya sesudah perlakuan lebih tinggi dari sebelum perlakuan. Selisih rata-rata nilai uji intensitas cahaya sebelum dan setellah perlakuan paling tinggi pada perendaman 18 jam dan paling rendah pada perendaman 6 jam. Resin komposit nanofiller mengalami perubahan warna setelah dilakukan perendaman dalam minuman susu fermentasi dengan perbedaan yang signifikan.
\end{abstract}

Kata kunci: Resin Komposit, Perubahan Warna, Estetik, Susu Fermentasi, Nanofiller

\section{Abstract}

Composite resin is one of filling material anterior that popular because it had advantages in the field of aesthetic and the same color as teeth. Nanofiller composites had mechanical properties better than microhybrid and could maintain smoothness during using as microfiller. Composite resin's color could change in the oral cavity, which could be caused by low pH beverage. Objective of this research to determined the influence of immersion in the fermented milk on the discoloration of nanofiller composite resin. In addition to know the difference of nanofiller composite resin discoloration in the fermented milk for 6,12 , and 18 hours. The type of this research was experimental laboratories with pretest and post test group design. 24 samples immersed in fermented milk for 6, 12, and 18 hours. The measurement of the color changing was using optical spectrophotometer to determine the light intensity value. To know the value of the discoloration was appeared from the value of the light intensity that appeared on the optical spectrophotometer. Analysis of data by using Paired-T Test and One Way Annova. The value of light intensity test was higher after treatment. The average difference of light intensity values before and after treatment was highest in 18 hours group and the lowest in 6 hours group. The discoloration of nanofiller composite resin after immersed in fermented milk had significant difference.

Keywords: Composite Resin, Discoloration, Esthetic, Fermented Milk, Nanofiller 


\section{PENDAHULUAN}

Resin komposit adalah bahan berbasis resin yang di dalamnya ditambahkan partikel pengisi (Anusavice, 2006). Resin komposit dapat diklasifikasikan berdasarkan ukuran partikel pengisi yaitu macrofiller, microfiller, dan nanofiller. Resin komposit hybrid adalah resin komposit yang terdiri dari dua jenis filler, diantaranya yaitu microhybrid dan nanohybrid. Komposit nanofiller memiliki sifat mekanik yang lebih baik dibandingkan microhybrid dan dapat mempertahankan kehalusan selama pemakaian seperti microfiller (Sakaguci \& Powers, 2012).

Resin komposit adalah salah satu jenis bahan tumpatan gigi anterior yang populer karena memiliki kelebihan dalam bidang estetik dan sewarna gigi. (Mukuan, Abidjulu \& Wicaksono, 2013). Masyarakat modern dewasa ini dalam mendapatkan perawatan kedokteran gigi berorientasi pada estetika (Anusavice, 2006). Komposit nanofiller diperkenalkan pada awal 1990-an, tetapi produk komersial pertama diluncurkan pada akhir tahun 2002 (Hamouda \& Elkader, 2012).

Perubahan warna yang terjadi pada resin komposit dapat disebabkan oleh berbagai hal, salah satunya yaitu faktor ekstrinsik (Wan, et.al, 2009). Faktor ekstrinsik yang dapat mempengaruhinya antara lain akumulasi plak dan stain, intensitas dan durasi polimerisasi, paparan faktor lingkungan, termasuk radiasi UV, panas, pewarna makanan serta minuman (Catelan, et.al, 2013). Minuman susu fermentasi adalah salah satu minuman yang populer di masyarakat. Penelitian mengenai preferensi konsumen terhadap minuman susu fermentasi di Kota Pekanbaru menunjukkan bahwa 33\% mengkonsumsi susu fermentasi setiap hari (Kasmadi, Mirdhayati, \& Rahmadani, 2011).

Orang yang sensitif terhadap produk susu pada umumnya dapat mengkonsumsi susu fermentasi oleh karena keberadaan bakteri di dalamnya dapat memetabolisme laktosa menjadi asam laktat. Susu fermentasi memiliki kandungan asam laktat dengan $\mathrm{pH}$ sekitar 4,2-4,8 (Widodo, Taufiq \& Anindita, 2013). $\mathrm{pH}$ rendah tersebut di atas dapat menyebabkan liberasi $\mathrm{H}+$ yang berdampak pada degradasi dan pemutusan ikatan rantai polimer, sehingga terjadi microvoids dan microcracks yang berada di antara matriks dan bahan pengisi resin dapat menjadi jalan masuk zat warna berpenetrasi ke dalam resin komposit (Nasim, et.al, 2010). Komponen matriks resin komposit memiliki sifat hidrofilik , sehingga mudah menyerap cairan di sekitarnya (Dewi, Yulianti, \& Munadziroh, 2012). Banyak ruang kosong di antara matriks polimer akan memudahkan terjadinya ikatan antara unsur yang ada pada cairan dengan matriks polimer (Villalta, et.al, 2006).

Perubahan warna pada resin komposit merupakan perubahan fisik yang dapat terlihat secara visual. Perubahan warna tersebut dapat disebabkan oleh faktor ekstrinsik, salah satunya yaitu minuman susu fermentasi. Perubahan warna salah satunya bisa dilihat dari nilai uji intensitas cahaya, yaitu jika semakin terang maka cahaya yang diabsorbsi semakin sedikit dan cahaya yang dipantulkan akan semakin banyak. 
Umumnya restorasi resin komposit dapat bertahan dalam rongga mulut selama 5-10 tahun (Opdam, et.al, 2005).

Penelitian ini akan dilakukan telaah tentang perubahan warna resin komposit nanofiller setelah perendaman dalam minuman susu fermentasi dengan berbagai variasi waktu berdasarkan latar belakang tersebut di atas.

\section{METODE PENELITIAN}

Jenis penelitian yang digunakan adalah eksperimental laboratories dengan rancangan penelitian desain grup pretest and post test. Penelitian ini dilaksanakan di Laboratorium Mikrobiologi Fakultas Kedokteran Gigi Universitas Jember, Klinik Konservasi Fakultas Kedokteran Gigi Universitas Jember, dan Laboratorium Optik dan Aplikasi Laser Jurusan Fisika Fakultas Sains dan Teknologi Universitas Airlangga pada bulan Februari 2015. Variabel penelitian ini adalah perubahan warna resin komposit nanofiller setelah perendaman dalam minuman susu fermentasi. Kriteria sampel yakni lempeng resin komposit berbentuk silindris dengan diameter $5 \mathrm{~mm}$ dan tinggi $2 \mathrm{~mm}$ dengan permukaan tidak porus dan tidak kasar. Sampel pada penelitian ini dibagi menjadi 3 kelompok $(n=8)$ sesuai lama perendaman, yaitu 6 jam, 12 jam, dan 18 jam. Alat yang digunakan untuk menguji perubahan warna yaitu spektrofotometer optik.

Prosedur penelitian dimulai dari pembuatan sampel kemudian diukur warna sebelum perlakuan (intensitas cahaya). Lalu dilakukan perendaman dalam minuman fermentasi selama 6 jam $\left(A_{1}\right), 12$ jam $\left(A_{2}\right)$, dan 18 jam $\left(A_{3}\right)$. Setelah itu diukur perubahan warna setelah perlakuan menggunakan spektrofotometer optik.

Data yang sudah ditabulasi kemudian diuji distribusi normalitasnya menggunakan uji kolmogorov-smirnov. Hasilnya data berdistribusi normal, maka dilanjutkan dengan uji komparatif Paired-T Test. Kemudian dilanjutkan uji homogenitas varian menggunakan uji Levene. Pengujian dilanjutkan dengan uji parametrik One Way Annova kemudian uji lanjut LSD (Least Significance Different).

\section{HASIL PENELITIAN}

Penelitian yang telah dilakukan, diperoleh hasil sebagai berikut:

Tabel 1. Selisih rata-rata nilai uji intensitas cahaya yang dipantulkan sampel pada kelompok sebelum dan setelah perlakuan (microVolt)

\begin{tabular}{lcccc}
\hline & \multicolumn{3}{c}{ Hasil uji intensitas cahaya (microVolt) } \\
\hline Kelompok & $\mathrm{N}$ & $\begin{array}{c}\text { Sebelum } \\
\text { perlakuan }\end{array}$ & $\begin{array}{c}\text { Setelah } \\
\text { perlakuan }\end{array}$ & Selisih \\
\hline 6 jam $\left(\mathrm{A}_{1}\right)$ & 8 & 1991 & 2065 & 74 \\
12 jam $\left(\mathrm{A}_{2}\right)$ & 8 & 2016 & 2155 & 99 \\
18 jam $\left(\mathrm{A}_{3}\right)$ & 8 & 2014 & 2218 & 204 \\
\hline
\end{tabular}


Tabel 1 menunjukkan bahwa nilai uji intensitas cahaya sesudah perlakuan lebih tinggi. Lama perendaman 6 jam, 12 jam, dan 18 jam menunjukkan bahwa yang paling besar selisihnya adalah pada pada kelompok perlakuan 18 jam perendaman $\left(\mathrm{A}_{3}\right)$ dan selisih rata-rata nilai uji intensitas cahaya sebelum dan setelelah perlakuan paling rendah pada kelompok perlakuan 6 jam $\left(\mathrm{A}_{1}\right)$.

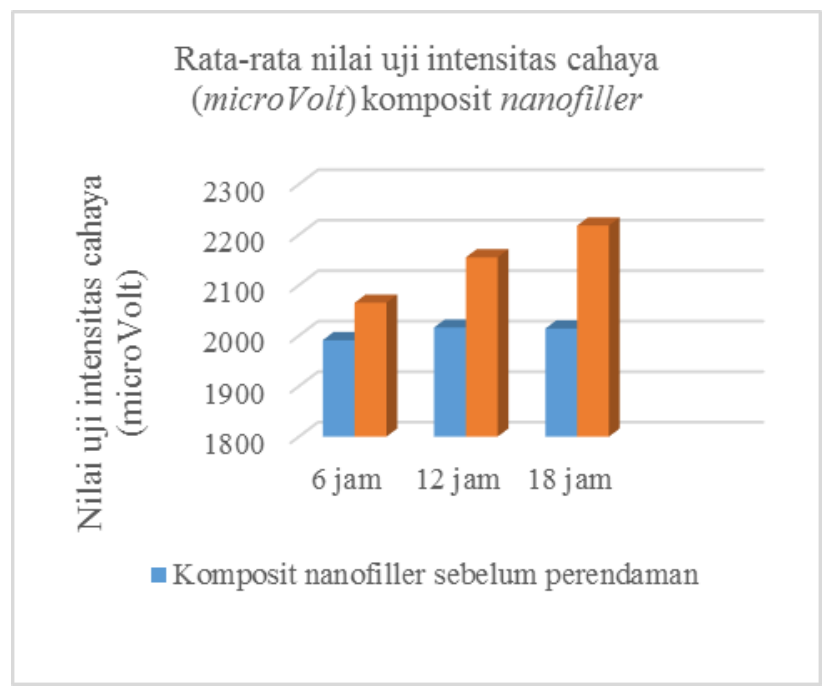

Gambar 1. Histogram rata-rata nilai uji intensitas cahaya (microVolt) komposit nanofiller

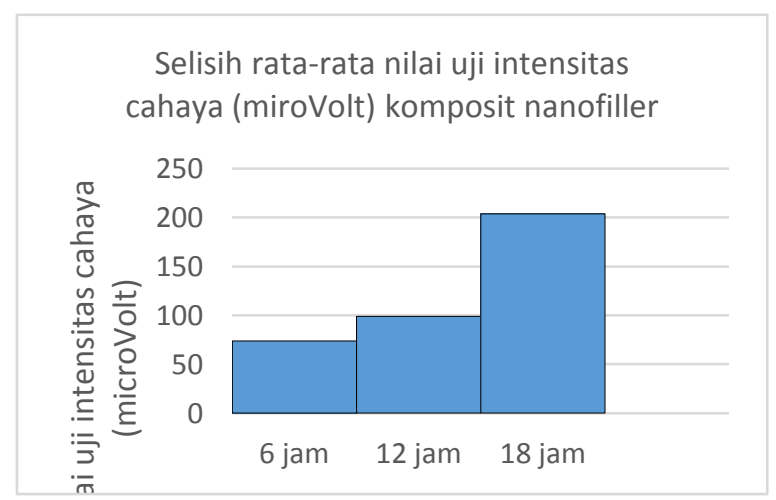

Gambar 2. Histogram selisih rata-rata nilai uji intensitas cahaya (microVolt) komposit nanofiller

Data hasil penelitian kemudian ditabulasi, dan diuji distribusi normalitasnya dengan uji Kolmogorov-Smirnov. Hasil yang didapatkan $\mathrm{p}>0,05$ artinya data tersebut terdistribusi normal. Selanjutnya dilakukan uji komparatif Paired-T Test, menunjukkan nilai signifikansi $<0,05$ artinya terdapat perbedaan bermakna antara sebelum dan setelah perlakuan. Analisis data dilanjutkan dengan uji homogenitas menggunakan uji Levene, dari uji ini diperoleh $p>0,05$ artinya bahwa data tersebut adalah homogen.

Data diketahui berdistribusi 
normal dan homogen, maka analisis data dilanjutkan dengan uji parametrik One Way Annova. Berdasarkan uji One Way Annova menunjukkan bahwa tidak terdapat perbedaan yang signifikan antar kelompok usia dengan nilai signifikansi sebesar $\mathrm{p}>0,05$. Untuk mengetahui lebih lanjut letak perbedaan bermakna pada masingmasing kelompok, maka analisis dilanjutkan dengan uji LSD (Least Significant Difference), dari uji ini terdapat perbedaan bermakna $(\mathrm{p}<$ $0,05)$ antar semua kelompok, yaitu antara $A_{1}$ dengan $A_{2}, A_{1}$ dengan $A_{3}$, dan antara $A_{2}$ dengan $A_{3}$.

\section{PEMBAHASAN}

Masyarakat moderen dewasa ini dalam mendapatkan perawatan kedokteran gigi berorientasi pada estetika (Adhidarma, Untara \& Iskandar, 2011). Salah satu bahan restorasi yang banyak digunakan karena memiliki keunggulan di bidang estetik yaitu resin komposit (Mukuan, Abidjulu \& Wicaksono, 2013). Resin komposit yang digunakan dalam penelitian ini adalah nanofiller yang mempunyai sifat mekanik lebih baik dibandingkan micohybrid dan dapat mempertahankan kehalusan selama pemakaian seperti microfiller (Sakaguci \& Powers, 2012).

Perubahan warna yang terjadi pada resin komposit dapat disebabkan oleh berbagai hal, salah satunya yaitu faktor ekstrinsik, diantaranya minuman dan makanan (Dewi S, Yulianti \& Munadziroh, 2012). Gaya hidup sehat merupakan trend baru masyarakat dunia yaitu dengan mengkonsumsi minuman dan makanan sehat. Salah satu minuman yang populer adalah susu fermentasi yang memiliki $\mathrm{pH} 3,7$.

Penelitian sebelumnya menyimpulkan bahwa telah terjadi perubahan warna pada resin komposit setelah direndam dalam minuman teh, kopi, dan wine (Aprilia \& Erry, 2007). Selain itu Dewi et al (2012) dalam penelitiannya melaporkan bahwa obat kumur yang mengandung alkohol maupun tidak mengandung alkohol juga dapat menyebabkan perubahan warna pada resin komposit.

Bahan resin komposit apabila berada di lingkungan berair akan mengakibatkan ikatan polimer mengembang sehingga komposit akan menjadi lebih lunak. Sifat fisik dari resin komposit tergantung pada kualitas polimer yang terbentuk, apabila kurang baik maka akan lebih rentan terhadap zat kimia yang masuk melalui makanan dan minuman. Hal ini mengakibatkan lebih mudah terjadi perubahan warna seiring waktu (Catelan, et.al, 2013).

Data deskriptif nilai uji intensitas cahaya (microVolt) kelompok komposit nanofiller setelah perendaman lebih tinggi dibandingkan sebelum perendaman (Tabel 1). Semakin tinggi intensitas cahaya yang diteruskan (microVolt) menunjukkan bahwa warna dari sampel semakin terang setelah menerima perlakuan dan sebaliknya (Aprilia \& Erry, 2007). Hasil ini menunjukkan bahwa setelah perendaman dalam susu fermentasi, sampel mengalami perubahan warna menjadi semakin terang. Komponen matriks resin komposit memiliki sifat hidrofilik (Dewi S, Yulianti \& Munadziroh, 2012). Hal ini memungkinkan resin komposit mudah menyerap cairan di sekitarnya 
termasuk susu fermentasi yang mengandung zat warna putih alami susu sehingga warna sampel menjadi lebih terang.

Semakin lama waktu perendaman, selisih rata-rata nilai uji intensitas cahaya (microVolt) kelompok sebelum dan setelah perlakuan semakin meningkat. Susu fermentasi memiliki $\mathrm{pH}$ yang rendah karena asam laktat yang terkandung di dalamnya (Agustina, Setyawardani \& Astuti, 2013). Asam laktat memiliki rumus kimia $\mathrm{C}_{3} \mathrm{H}_{6} \mathrm{O}_{3}$. Kelebihan ion $\mathrm{H}$ pada asam dapat menyebabkan pemutusan ikatan antara rantai polimer. $\mathrm{H}+$ dapat mengikat ion COO- pada gugus $\mathrm{CO}_{2} \mathrm{CH}_{3}$ pada polimer sehingga terpecah menjadi $\mathrm{COOH}$ dan $\mathrm{CH}_{3}$. $\mathrm{H}+$ juga dapat menyebabkan terputusnya ikatan ganda pada senyawa dimetakrilat pada principal monomer. Hal ini menyebabkan degradasi dan pemutusan ikatan rantai polimer terutama pada gugus ester. Ester dapat terhidrolisis oleh air pada suasana asam yang akan menghasilkan asam karboksilat dan alkohol. Hal tersebut di atas dapat menyebabkan microvoids dan microcracks yang berada di antara matriks dan bahan pengisi resin dapat menjadi jalan masuk zat warna berpenetrasi ke dalam resin komposit (Nasim, et.al, 2010). Banyak ruang kosong di antara matriks polimer akan memudahkan terjadinya ikatan antara unsur yang ada pada cairan dengan matriks polimer (Villalta, et.al, 2006). Hal ini yang mengakibatkan semakin lama perendaman dalam susu fermentasi, maka ikatan polimer pada resin komposit semakin banyak yang terputus, Microcracks dan microvoids yang menjadi jalan masuk penetrasinya zat warna ke dalam resin komposit semakin banyak terbentuk. Oleh karena itu semakin lama perendaman resin komposit, bertambah banyak pula menyerap cairan sehingga warna sampel menjadi semakin terang. Hal ini terbukti dengan hasil penelitian yang menunjukkan bahwa 6 jam perendaman memiliki selisih ratarata nilai uji intensitas cahaya paling rendah dan 18 jam paling tinggi.

$\mathrm{pH}$ susu fermentasi yang digunakan pada penelitian ini bersifat asam. Kandungan $\mathrm{pH}$ rendah dapat mempengaruhi integritas permukaan resin komposit yang dapat menyebabkan perubahan warna. Beberapa monomer dari resin akan melepaskan diri disertai pelepasan bahan pengisi di dalamnya. Hal ini akan menyebabkan banyak ruang kosong di antara matriks polimer, sehingga memudahkan terjadinya ikatan antara unsur yang ada pada cairan dengan matriks polimer (Villalta, et.al, 2006).

$$
\text { Pembahasan di atas }
$$

didapatkan hasil bahwa komposit nanofiller mengalami perubahan warna (lebih terang) setelah dilakukan perendaman pada minuman susu fermentasi dibandingkan dengan sebelum perendaman. Hal ini sesuai dengan dugaan sementara (hipotesis) yang disimpulkan peneliti sebelum pelaksanaan penelitian, yaitu terdapat perubahan warna pada resin komposit nanofiller setelah dilakukan perendaman dalam minuman susu fermentasi.

\section{SIMPULAN DAN SARAN}

Hasil penelitian yang dilakukan dapat disimpulkan bahwa terdapat perubahan warna pada resin 
komposit nanofiller setelah dilakukan perendaman dalam minuman susu fermentasi, yaitu semakin lama perendaman, menunjukkan perubahan warna semakin terang. Terdapat perbedaan yang signifikan tentang perubahan warna resin komposit nanofiller dengan lama perendaman 6,12 , dan 18 jam.

Saran yang dapat diberikan diantaranya perlu dilakukan penelitian lebih lanjut menggunakan SEM (Scanning Electron Microscope) untuk melihat microporosity pada permukaan resin komposit setelah perendaman dalam susu fermentasi.

\section{DAFTAR PUSTAKA}

Adhidarma, T., Untara, T.E., dan Iskandar, B. 2011. Restorasi Estetik Resin Komposit dengan Color Modifier pada Gigi Insisivus Sentralls Makslla Hipoplasia Enamel Kavitas Kelas IV. [online]. http://i-

lib.ugm.ac.id/jurnal/detail.ph p?dataId=11876. [20 Oktober 2014].

Agustina, L., Setyawardani, T., Astuti, T. A. 2013. Penggunaan Starter Biji Kefir dengan Konsentrasi yang Berbeda pada Susu Sapi Terhadap Ph dan Kadar Asam Laktat. Purwokerto: Jurnal Ilmiah Peternakan Vol. 1 (1): 254-259.

Al-Shalan T. A. 2009. In Vitro Staining of Nanocomposite Exposed to a Cola Beverage. Saudi Arabia: Pakistan Oral and Dental Journal. Halaman
79-84.

Anusavice, K. J. Phillips Buku Ajar Ilmu Bahan Kedokteran Gigi. Terjemahan oleh Johan Arief Budiman dan Susi Purwoko. 2006. Jakarta: EGC. Halaman 237-243.

Aprilia, L. R. dan Erry, R. 2007. Pengaruh Minuman Kopi Terhadap Perubahan Warna Pada Resin Komposit. Indonesian Journal of Dentistry. Vol.14 (3): 164170.

Catelan, Barbosa, Suzuki, Barreto, Giorgi, Goiato, Santos, Aguiar. 2013. Composite Resin Susceptibility to Red Wine Staining after Water Sorption. Journal of Research in Dentistry. Vol. 1 (2): 114118.

Dewi S. K., Yulianti A., dan Munadziroh E. 2012. Evaluasi Perubahan Warna Resin Komposit Hybrid setelah Direndam Obat Kumur. Jurnl PDGI. Vol. 61 (1): 5-9.

Hamouda I. M., dan Elkader H. A. 2012. Evaluation the Mechanical Properties of Nanofilled Composite Resin Restorative Material. Egypt: Journal of Biomaterials and Nanobiotechnology. Vol. 3: 238-242.

Kasmadi, Mirdhayati I., Rahmadani E. 2011. Preferensi Konsumen terhadap Minuman Susu Fermentasi di Tiga Mall Kota Pekanbaru. Jurnal Peternakan. Vol. 8 (1): 27-37. 
Mukuan, T., Abidjulu J., dan Wicaksono D.A. 2013. Gambaran Kebocoran Tepi Tumpatan Pasca Restorasi Resin Komposit pada Mahasiswa Program Studi Kedokteran Gigi Angkatan 2005-2007. Jurnal E-Gigi (Eg). Vol 1 (2): 115-120.

Nasim, Prasanna,Sujeer, Subbarao. 2010. Color Stability of Microfilled, Microhybrid, and Nanocomposite resin - An in Vitro Study. India: Journal of Dentistry. Halaman 137-142.

Opdam, N. J. M., Bronkhorst, E. M., Roeters, J. M., Loomans, B. A. C. 2005. A Retrospective Clinical Study on Longevity of Posterior Composite and Amalgam Restorations. Netherlands: Dental Material. Vol 23 (1): 2-8.

Sakaguci, L.R. \& Powers, J.M. 2012. Craig's Restorative Dental Materials. 13th Ed. Philadelpia: Elsevier.161-198.

Villalta, Huan, Franklin, Power. 2006. Effect Of Staining and Bleaching on Color Change of Dental Composite Resins. The Journal of Prosthetic Dentistry 95 (Issue 2): 13742.

Wan Bakar W.Z, Azrizal M., dan Husein A. 2009. A Comparison of Staining Resistant of Two Composite Resins. Malaysia: School of Dental Science. Halaman 1316.

Widodo, Taufiq T. T. dan Anindita N. S. 2013. Fermented Goat Milk and Cow Milk Produced by Different Starters of Lactic
Acid Bacteria: Quality Studies. Journal of Agricultural Science and Technology. Halaman 904911. 